\title{
Determination of Sleep Quality of Hospitalized Patients in a Neurosurgery Clinic
}

\section{Nöroșirürji Kliniğinde Yatan Hastaların Uyku Kalitesinin Belirlenmesi}

\author{
(1) Remziye Cici, (10 Meral Özkan*
}

Hitit University Faculty of Health Sciences, Department of Nursing, Çorum, Turkey

*Inönü University Faculty of Nursing, Department of Surgical Diseases Nursing, Malatya, Turkey

\begin{abstract}
Objective: This study aimed to determine the sleep quality of patients in a neurosurgery clinic.

Materials and Methods: This descriptive study was conducted between April 2013 - March 2014 with hospitalized patients aged $\geq 18$ years in a neurosurgery clinic of a university hospital in Turkey. All patients in the neurosurgery clinic were included. The study sample consisted of 140 patients who were selected using improbable random sampling method. Data were collected via questionnaire, including patient identification form and Pittsburgh Sleep Quality index. Mean, percentages, independent t-test, Kruskal-Wallis, and analysis of variance were used to analyze the data. Significance was determined for $p<0.05$. Results: The mean Pittsburgh sleep quality index score of the patients was poor (7.63 \pm 4.04$)$. In addition, subjective sleep quality, sleep latency, sleep duration, and sleep disorder sub-component scores were poor, whereas habitual sleep activity, sleep medication use, and daytime sleep dysfunction sub-component scores were good. Female patients had poor sleep quality compared with male patients $(p<0.05)$.

Conclusion: This study showed that neurosurgery patients have statistically significant poor sleep quality.
\end{abstract}

Keywords: Neurosurgery, Patient, Sleep quality
Öz

Amaç: Bu araştırma nöroşirürji kliniğinde yatan hastaların uyku kalitesini belirlemek amacıyla gerçekleştirildi.

Gereç ve Yöntem: Araştırma tanımlayıcı olarak, Türkiye'de bir üniversite hastanesinin nöroşirürji kliniğinde Nisan 2013 - Mart 2014 tarihleri arasında yürütüldü. Araştırmanın evrenini nöroşirürji kliniğinde yatan tüm hastalar oluşturdu. Örneklemini ise 18 yaş ve üzerinde olan olasılıksız gelişigüzel örnekleme yöntemi ile seçilen 140 hasta oluşturdu. Araştırmaya başlamadan önce çalışmanın yapıldığı kurumdan ve etik kuruldan gerekli onaylar alındı. Veriler hasta tanıtım formu ve Pittsburg Uyku Kalitesi indeksi kullanılarak yüz yüze görüşme yöntemiyle toplandı. Verilerin istatistiksel değerlendirilmesinde sayı, yüzde, ortalama ve standart sapma, bağımsız gruplarda t-testi, Kruskal-Wallis ve ANOVA testleri kullanıldı.

Bulgular: Araştırmaya katılan hastaların Pittsburg Uyku Kalitesi indeksi toplam puan ortalamasının kötü $(7,63 \pm 4,04)$ olduğu belirlendi. Öznel uyku kalitesi, uyku latensi, uyku süresi ve uyku bozukluğu alt bileșen puanı kötü, alışılmış uyku etkinliği, uyku ilacı kullanımı ve gündüz işlev bozukluğu alt bileșen puanı ise iyi olarak bulundu. Kadın hastaların erkek hastalara göre uyku kalitelerinin daha kötü olduğu bunun dışında hastaların diğer tanıtıcı ve tıbbi özelliklerinin uyku kalitesini önemli düzeyde etkilemediği belirlendi.

Sonuç: Sonuç olarak nöroşirürji hastalarının uyku kalitesinin önemli düzeyde kötü olduğu saptandı.

Anahtar Kelimeler: Nöroşirürji, Hasta, Uyku kalitesi

\section{Introduction}

As bio-psycho-socio-cultural entities, human beings need to meet their basic needs in order to live healthily. Sleep is a physiological need in Maslow's pyramid and a basic human need in nursing theories $(1,2)$. Sleep- an important health measure affects life quality, development and renewal of body, and learning and memory functions (2-4).

Sleep quality is defined as an individual's feeling fit, energetic and ready for a new day after waking up $(5,6)$. Life style, environment and stress can negatively affect sleep quality $(4,6)$. Hospitalization is another negative factor (7). The number of

Address for Correspondence/Yazışma Adresi: Remziye Cici MD, Hitit University Faculty of Health Sciences, Department of Nursing, Çorum, Turkey Phone: +90 36422307 30/3508 E-mail: remziyecici@hotmail.com ORCID-ID: orcid.org/0000-0003-3977-492X Received/Geliş Tarihi: 15.04.2020 Accepted/Kabul Tarihi: 03.08.2020

${ }^{\circ}$ Copyright 2020 by Turkish Sleep Medicine Society / Journal of Turkish Sleep Medicine published by Galenos Publishing House. 
patients in the hospital room, duration of hospital stay, light and noise level, and the structure of the bed are hospital-related factors $(4,8-10)$. A previous study found that in terms of sleep quality $45.5 \%$ of the patients were negatively affected by the interference, and $40 \%$ by the entry into and exit from the room (10).

Patients suffer from insomnia due to illness symptoms (7). Pain and discomfort are experienced in neurosurgery clinics and cause insomnia. Head trauma, aneurysms, tumors and intracranial surgeries cause headache, and spinal cord tumors and disc hernias cause pain. Headaches occur early in the morning, and can wake the patient from sleep (11-13). Neurosurgery patients are said to frequently experience sleep problems caused by pain, which negatively affects sleep quality (14-16). Nausea and vomiting negatively affect sleep quality as well (13) especially in patients diagnosed with head trauma, aneurysm, hematoma and mass $(17,18)$

Some studies have focused on sleep problems after brain trauma (15), sleep quality in lumbar disc herniation patients (16) and in patients with spinal cord injury (14), and sleep disorder and/or sleep quality in patients with chronic lumbar pain (19). These studies each focus on one diagnosis; however, patients are hospitalized with many different diagnoses (mass, aneurysm, trauma, hematoma, disc hernia etc) in neurosurgery clinics $(12,13)$. One of the studies examining sleep quality without distinguishing between diagnoses is the study of Sendir et al. (20), which was conducted long time ago. Factors affecting sleep quality may have changed with science and technology. Thus, new studies on sleep quality of neurosurgery patients are needed.

This study aimed to determine the sleep quality of hospitalized patients in a neurosurgery clinic.

\section{Materials and Methods}

This descriptive and cross-sectional study research was conducted in a neurosurgery clinic of a hospital in Turkey between April 2013 and March 2014. The neurosurgery clinic where ten nurses work had 12 rooms and thirty beds in total and it usually operates at full capacity. Both adult and pediatric patients are treated in the clinic. Three rooms had a maximum capacity of five patients, while six rooms accomodate two patients, and three rooms are single patient rooms. Patient treatment and care starts at $6.00 \mathrm{a} . \mathrm{m}$. and is scheduled to continue regularly until 00.00 a.m. The Glasgow Coma scale and vital sign evaluations of the patients who are planned to have cranial surgery and who are in the first 24 hours of postoperative stage are made at 2.00 a.m. Visitor hours are from 2.00 to 3.00 p.m. in the afternoon and from 7.00 to 8.00 p.m. in the evening. Each patient has at least one attendant. The data was collected in the specified neurosurgery clinic every weekday. The patients were informed about the aim of the study. Those who volunteered to participate in the study and who signed the informed consent forms were included in the study. The participants were informed about the Patient Identification Form and the Pittsburgh Sleep Quality index scale. These forms were filled in by one of the researchers through face to face interviews and during daytime hours when the patients felt more comfortable. The data collection process took about 15 to 20 minutes for each patient.

The target population of the study was all the patients in the neurosurgery clinic. The sample of the study was chosen with the non-probable sampling method. Hospitalized patients aged $\geq 18$ years for at least one week without vision, hearing and communication problems and who had an operation were included in the study. Patients who had diagnosed any psychiatric disease and sleep disorders and those who use drugs that affect sleep quality were excluded the study. In the studies conducted in our country, the total score of PSQI was found as $8.29 \pm 5.03$ (20) and 8.090 \pm 3.504 (21). Based on these studies, according to the power analysis and the criteria of 0.40 effect size, 0.05 error level, and 0.95 target population representation power, minimum sample size calculated as 125 patients. Study was completed with 140 patients.

\section{Patient Identification Form}

The Patient Identification Form includes questions to learn about the basic characteristics (age, gender, marital status, education level, working status, place of residence etc) and the medical characteristics (diagnosis, presence of a chronic disease, hospitalization experience, surgery experience, etc) of patients.

\section{Pittsburgh Sleep Quality Index}

The scale was developed in 1989 by Buysse et al. (21). The validity and reliability study of the scale was conducted by Ağargün et al. (5) in Turkey in 1996. The Cronbach's alpha of the scale was 0.804 .

The scale includes 24 questions and 7 components. In the scale 19 of the questions are self-report questions, while the remaining five questions are answered by a spouse or a roommate. The question regarding the existence of a partner and five questions answered by the spouse and roommates (6 questions in total) are used only as clinical data; they are not included in the scoring process. The components of the scale are subjective sleep quality (component 1), sleep latency (component 2), sleep duration (component 3), habitual sleep activity (component 4), sleep disorder (component 5), sleep medication use (component 6), and daytime sleep dysfunction (component 7). Some of the components include one item, while some components are obtained through the grouping of several items. Responses to each item are scored between 0-3 points according to symptom frequency. To be more specific, no occurrence is scored as 0 , occurrence less than once a week is scored as 1, occurrence once or twice a week is scored as 2 , and occurrence three or more times a week is scored as 3. The total scale score is between 0 and 21 . Sleep quality is considered to be clinically poor if the total score is above 5 . The sub-component scores obtained from the PSQI are interpreted as follows: 0 - very good, 1-quite good, 2-quite bad, and 3-very bad. It is observed that as the score obtained from the scale increases, sleep quality worsens $(5,22)$. 


\section{Statistical Analysis}

Data was analysed by using SPSS 16.0 progrrammes with percentages, mean parametric and non-parametric methods (t-test, Kruskal-Wallis and ANOVA in independent groups). The results were evaluated at $95 \%$ confidence interval and significance level was set at $p<0.05$.

\section{Results}

It was found that $40 \%$ of the patients were 51 years or older; $56.4 \%$ were male; $77.9 \%$ were married; $50 \%$ were primary school graduates; $60.7 \%$ did not work, and $43.5 \%$ lived in the city center. The difference between the mean PSQI total scores of the patients according to age, marital status, educational status, working status and place of residence was not statistically significant $(p>0.05)$. However, the total mean PSQI score of the women $(8.40 \pm 3.99)$ was higher than that of men $(6.96 \pm 4.02)$ $(\mathrm{p}=0.036)$ (Table 1$)$.

When the distribution of some patient characteristics according to sleep quality examined, it was observed that $33.6 \%$ of patients had intracranial mass, $20.7 \%$ had a chronic disease, $67.1 \%$ had hospital experience and $57.1 \%$ had surgical experience. When the duration of stay in the clinic examined, it was seen that $47.9 \%$ were in the clinic for $8-14$ days and $45 \%$ were in a 5 -person room (Table 2).
Table 2 shows that the diagnosis of the patients, chronic disease presence, hospitalization experience and surgery experience, duration of stay in the neurosurgery clinic, and room specifications did not affect the total PSQI scores.

Total and sub-component score averages of the patients obtained from the PSQI were displayed in Table 3. It can be observed that the total average PSQI score of the patients in the study was $7.63 \pm 4.04$. The average scores for the subcomponents were $1.38 \pm 1.01$ for subjective sleep quality, $1.52 \pm 1.07$ for sleep latency, $1.57 \pm 1.07$ for sleep duration, $0.61 \pm 0.94$ for habitual sleep activity, $1.29 \pm 0.53$ for sleep disorder, $0.41 \pm 0.90$ for sleep medication use, and $0.82 \pm 0.97$ for daytime sleep dysfunction (Table 3 ).

\section{Discussion}

While inpatients try to cope with the effects of their illnesses, they also try to adapt to the negative effects of hospitalization, one of which is poor sleep quality. This situation affects the recovery process negatively. Therefore, sleep quality should be kept at the best level possible $(3,11)$.

The present study revealed that sleep quality did not differ across different age groups (Table 1 ). Similar results were obtained in other studies as well $(8,20)$. Neurosurgical patients may experience physical limitations and pain due to their illness

\begin{tabular}{|c|c|c|c|c|}
\hline Basic characteristic & Number & $\%$ & PSQI & Test \\
\hline \multicolumn{5}{|l|}{ Age } \\
\hline $\begin{array}{l}\text { Woman } \\
\text { Men }\end{array}$ & $\begin{array}{l}61 \\
79 \\
\end{array}$ & $\begin{array}{l}43.6 \\
56.4 \\
\end{array}$ & $\begin{array}{l}8.40 \pm 3.99 \\
6.96 \pm 4.02 \\
\end{array}$ & $\begin{array}{l}t=2.117 \\
p=0.036\end{array}$ \\
\hline \multicolumn{5}{|l|}{ Marital status } \\
\hline $\begin{array}{l}\text { Married } \\
\text { Single }\end{array}$ & $\begin{array}{l}109 \\
31\end{array}$ & $\begin{array}{l}77.9 \\
22.1\end{array}$ & $\begin{array}{l}7.51 \pm 3.87 \\
7.87 \pm 4.72\end{array}$ & $\begin{array}{l}t=0.431 \\
p=0.667\end{array}$ \\
\hline \multicolumn{5}{|l|}{ Working status } \\
\hline $\begin{array}{l}\text { Working } \\
\text { Non-working }\end{array}$ & $\begin{array}{l}55 \\
85 \\
\end{array}$ & $\begin{array}{l}39.3 \\
60.7 \\
\end{array}$ & $\begin{array}{l}7.45 \pm 3.98 \\
7.68 \pm 4.13 \\
\end{array}$ & $\begin{array}{l}t=0.323 \\
p=0.747\end{array}$ \\
\hline \multicolumn{5}{|l|}{ Place of residence } \\
\hline $\begin{array}{l}\text { Village/town } \\
\text { District } \\
\text { City }\end{array}$ & $\begin{array}{l}47 \\
32 \\
61\end{array}$ & $\begin{array}{l}33.6 \\
22.9 \\
43.5\end{array}$ & $\begin{array}{l}7.44 \pm .0 .41 \\
8.00 \pm 4.31 \\
7.49 \pm 4.42\end{array}$ & $\begin{array}{l}F=0.208 \\
p=0.813\end{array}$ \\
\hline
\end{tabular}


$(13,14,20)$. Therefore, it is thought that there is no statistically significant difference between age groups and that problems are present in all age groups.

A statistically significant finding was that women have worse sleep quality (Table 1). Similar results were obtained in the studies of Ertekin (22) and Dogan et al. (23) This finding may be attributed to women's sensitivity to the changes in sleep rhythm and psychological state. Also, Turkish women are thought to have more responsibilities in the triangle of home-child-spouse in line with the norms of the society and have difficulty in fulfilling these responsibilities during the hospitalization process.

Experience can help cope with difficult situations when they are encountered again. Thus, patients with previous hospitalization and surgery experience are expected to experience fewer sleep problems. However, the present study revealed no statistically significant difference between the sleep qualities of the patients (Table 2). As opposed to the findings of our study, Sendir et al. (20) found that previous hospital experience has a negative effect on sleep quality.

Among the patients who stayed the neurosurgery clinic between 15-21 days, PSQI scores were highest (Table 2). The results of some studies in the literature coincide with the findings of our study $(7,8,10,21)$ In the hospitalization process, sleep quality is affected negatively due to the feelings of uncertainty and adaptation to the hospital environment. Only after the adaptation stage, sleep quality can improve. Still, sleep quality is considered to be poor due to the lack of the order in the home environment and prolonged hospitalization.

In contrast to the findings of Karagözoglu (10), our study revealed that room specifications did not affect sleep quality (Table 2), which indicates that poor sleep quality can be associated with the illness, symptoms, new environment and patient psychology rather than room specifications.

In our study, sleep quality of patients in the neurosurgery clinic was found to be poor. Sendir et al. (20) also reached a similar result. It is stated in the literature that pain, movement restriction and paresthesia affect sleep quality negatively $(4,8,10,13,14,24)$ In their studies conducted at the neurosurgery intensive care unit and in the neurosurgery clinic, Altun Ugras and Oztekin (11), Sendir et al. (20) found that pain affects sleep quality negatively. Southwell and Wistow (25) found that hospitalized patients' sleep quality was negatively affected by movement restriction, and Bradley Feenstra (14) revealed that patients with spinal cord injuries suffer from poor sleep quality due to paresthesia and spasm. Although the present study did not evaluate the effect of pain, movement restriction, paresthesia and spasm on sleep quality, it is believed that the sleep quality of the patients in our study was impaired by these factors.

Our study also revealed that subjective sleep quality was poor (Table 3). This finding was similar to that of Dogan et al. (23) In the literature, pain and anxiety were found to adversely

\begin{tabular}{|c|c|c|c|c|}
\hline Factors that can affect sleep quality & Number & $\%$ & PSQI & Test \\
\hline \multicolumn{5}{|l|}{ Diagnosis } \\
\hline \multicolumn{5}{|l|}{ Chronic disease } \\
\hline $\begin{array}{l}\text { Present } \\
\text { Non-present }\end{array}$ & \begin{tabular}{|l|}
29 \\
111 \\
\end{tabular} & $\begin{array}{l}20.7 \\
79.3 \\
\end{array}$ & $\begin{array}{l}8.31 \pm 4.78 \\
7.40 \pm 3.85\end{array}$ & $\begin{array}{l}t=1.069 \\
p=0.287\end{array}$ \\
\hline \multicolumn{5}{|l|}{ Hospitalization experience } \\
\hline \multicolumn{5}{|l|}{ Days in neurosurgery clinic } \\
\hline $\begin{array}{l}7 \\
8-14 \\
15-21 \\
22 \text { and above }\end{array}$ & $\begin{array}{l}40 \\
67 \\
22 \\
11\end{array}$ & \begin{tabular}{|l|}
28.6 \\
47.9 \\
15.7 \\
7.9 \\
\end{tabular} & $\begin{array}{l}6.62 \pm 3.96 \\
8.07 \pm 3.89 \\
8.40 \pm 4.38 \\
7.09 \pm 4.32\end{array}$ & $\begin{array}{l}K W=4.410 \\
p=0.220\end{array}$ \\
\hline \multicolumn{5}{|c|}{ Room specifications in neurosurgery clinic } \\
\hline $\begin{array}{l}\text { Single patient } \\
\text { Double patient } \\
5 \text { Patient }\end{array}$ & \begin{tabular}{|l|}
21 \\
56 \\
63 \\
\end{tabular} & $\begin{array}{l}15.0 \\
40.0 \\
45.0\end{array}$ & $\begin{array}{l}9.38 \pm 4.86 \\
7.67 \pm 3.79 \\
6.92 \pm 3.87\end{array}$ & $\begin{array}{l}K W=4.879 \\
p=0.087\end{array}$ \\
\hline
\end{tabular}




\begin{tabular}{|c|c|}
\hline Total and Sub-component & $\operatorname{Avg} \pm S D$ \\
\hline Total PSQI & $7.63 \pm 4.04$ \\
\hline Subjective sleep quality & $1.38 \pm 1.01$ \\
\hline Sleep latency & $1.52 \pm 1.07$ \\
\hline Sleep duration & $1.57 \pm 1.07$ \\
\hline Habitual sleep activity & $0.61 \pm 0.94$ \\
\hline Sleep disorder & $1.29 \pm 0.53$ \\
\hline Sleep medication use & $0.41 \pm 0.90$ \\
\hline Daytime sleep dysfunction & $0.82 \pm 0.97$ \\
\hline
\end{tabular}

affect sleep quality $(24,26)$. Poor subjective sleep quality may be caused by anxiety, pain, nausea, vomiting and movement restrictions.

The average sleep latency score was found to be poor (Table $3)$, which indicates that patients have difficulty falling asleep. This finding coincides with the findings of many other studies $(7,8,20)$. The reason behind this finding may be the difficulty in adapting to the hospital environment and the problems associated with the disease.

In this study, habitual sleep activity score was found to be good similar to the finding of Yalcın Atar et al. (7) (Table 3). This finding leads to the assumption that sleep habits of a patient are not seriously affected during the hospitalization period.

Sleep disorder is defined as having difficulty in falling asleep, maintaining sleep, waking up from sleep, the presence of nonrestorative sleep, and daytime sleeping (27). In this study, sleep disorder average score was found to be poor (Table 3 ), which coincides with the findings in the literature $(7,8,20,23)$. It was known that illness, hospital environment, treatment and care interventions cause sleep disorder. Accordingly, Onler et al. (3) found that $23.8 \%$ of the patients were negatively affected by the interventions during sleep time.

Sleep medication use score was found to be good as in the study of Sendir et al. (20) (Table 3). This finding may have resulted from the fact that there is no non-ordered medication application in the clinic where the study was conducted.

Daytime sleep dysfunction score of the patients was also found to be good (Table 3). This result shows that sleep problems do not affect daily activities. The studies of Yalcın Atar et al. (7) and Jolfaei et al. (8) alo supported this finding.

\section{Study Limitations}

The limitations of this study were that the sample was determined using the random sampling method and the results can be generalized only to this study.

\section{Conclusion}

It was found that the sleep quality of the patients in the study was poor. It was further revealed that the subjective sleep quality of the patients was poor; they had difficulty falling asleep; and they suffer from sleep disorders. The study also found that the habitual sleep activity of the patients did not change; the patients did not have the habit of taking sleeping pills; and their sleep problems did not cause daytime dysfunctions. It was found that female patients had worse sleep quality, and sleep quality did not differ as far as the factors other than gender are concerned.

\section{Ethics}

Ethics Committee Approval: This study involving human participants is in accordance with the ethical standards of the institutional and/or national research committee and with the 1964 Helsinki declaration and its later amendments or comparable ethical standards.

Necessary approvals were obtained from the institution (68636013 / BH / 170.99_1960) and the ethics committee (protocol no: 2013/47) before starting the study.

Informed Consent: The patients were informed about the research and their verbal and written consent was obtained.

Peer-review: Internally peer-review.

\section{Authorship Contributions}

Surgical and Medical Practices: R.C., M.Ö., Concept: M.Ö., R.C., Design: M.Ö., R.C., Data Collection or Processing: R.C., Analysis or Interpretation: R.C., M.Ö., Literature Search: R.C., Writing: R.C., M.Ö.

Conflict of interest: There is no conflict of interest between the authors of this article and no financial support has been received from a person or an institution. The authors declare they have no conflicts of interest.

Financial Disclosure: The authors declared that this study received no financial support.

\section{References}

1. Akca Ay F. Professional basic concepts. In: F. Akca Ay (ed). Basic concepts and skills in health practices. Istanbul: Nobel Medical Bookstores; 2011;4.

2. Birol L. Nursing process. İzmir: Etki Publications. 10. edition; 2011.

3. Onler E, Yılmaz A. The sleep quality of the patients in surgical units. Florence Nightingale Journal of Nursıng 2008;16:114-21.

4. da Costa SV, Ceolim MF. Factors that affect inpatients' quality of sleep. Rev Esc Enferm USP 2013;47:46-52.

5. Ağargün MY, Kara $H$, Anlar Ö. The validity and reliability of the pittsburgh sleep quality index. Turkish Journal Of Psychiatry 1996;7:107-15.

6. Senol V, Soyuer F, Peksen Akca R, Argün M. The sleep quality in adolescents and the factors that affect it. Kocatepe Medical Journal 2012;14:93-102.

7. Yalcın Atar N, Kırbıyık E, Kaya N, Kaya H. Patients' sleep quality and factors affecting sleep in surgery clinic of one university hospital. Turkiye Klinikleri Journal of Nursing Sciences 2012;4:74-84.

8. Jolfaei AG, Makvandi A, Pazouki A. Quality of sleep for hospitalized patients in Rasoul-Akram Hospital. Med I Islam Repub Iran 2014;28:73.

9. Ödül Özkaya B, Yüce Z, Gönenç M, Gül A, Alış H. Factors affecting the sleep patterns of hospitalized patients during the early postoperational period. BTDMJB 2013;9:121-5.

10. Karagözoğlu S, Çabuk S, Tahta $Y$, Temel F. Some factors influencing the sleep of hospitalized adult patients. Turk Thorac J 2007;8:234-40.

11. Altun Uğraş G, Oztekin SD. Patient perception of enviromental and nursing factors contributing to sleep disturbances in a neurosurgical intensive care unit. Tohoku J Exp Med 2007;212:299-308. 
12. Altun Uğraș G, Yuksel S, Sayın Y. Öztekin SD. Neurosurgical Nursing. İstanbul Nobel Medical Bookstores; 2015.

13. Altun Ugraş G, Akyolcu N. Nervous System Diseases and Care. In: Akyolcu N, Kanan N, Aksoy G (eds). Surgical Nursing II. İstanbul: Nobel Medical Bookstores, 2017;515-612.

14. Bradley Feenstra S. Paın, sleep, and mood in spinal cord injury, A Thesis Submitted in Partial Fulfillment of the Requirements for the Degree of Bachelor of Science with Honors in Neuroscience. University of Michigan, 2012.

15. Grima N, Ponsford J, Rajaratnam SM, Mansfield D, Pase MP. Sleep disturbances in traumatic brain Injury: a meta-analysis. J Clin Sleep Med 2016;12:419-28.

16. Kose G, Tastan S, Temiz NC, Sari M, Izci Y. The effect of low back pain on daily life activities and sleep quality in lumbar disc herniation: A Pilot Study. J Neurosci Nurs 2019;51:184-9.

17. Aksoy G. Pre-operative nursing care. In: Kanan N, Akyolcu N, Aksoy G (eds). Surgical Nursing I. İstanbul: Nobel Medical Bookstores; 2012;261-2.

18. Albayrak SA, Uçak Erden H, Erkal S, Köşkeroğlu N, Ançel G. Neurological Sciences Nursing. Ankara: Alter Publishing; 2006.

19. Iglesias-González J), Muñoz-García MT, Rodrigues-de-Souza DP, Alburquerque-Sendín F, Fernández-de-Las-Peñas C. Myofascial trigger points, pain, disability, and sleep quality in patients with chronic nonspecific low back. Pain Med 2013;14:1964-70.

20. Sendir M, Acaroglu R, Kaya H, Erol S, Akkaya Y. Evaluation of quality of sleep and effecting factors in hospitalized neurosurgical patients. Neurosciences (Riyadh) 2007;12:226-31.

21. Buysse DJ, Reynolds CF 3rd, Monk TH, Berman SR, Kupfer DJ. The pittsburgh sleep quality index: a new instrument for psychiatric practice and research. Psychiatry Res 1989;28:193-213.

22. Ertekin S. Evaluation of sleep quality in hospitalized patients. Master Thesis, Cumhuriyet University, Sivas, Turkey, 1998.

23. Dogan O, Ertekin S, Dogan S. Sleep quality in hospitalized patients. J Clin Nurs 2005; 14:107-13.

24. Yılmaz M, Sayin Y, Gurler H. Sleep quality of hospitalized patients in surgical units. Nurs Forum 2012;47:183-92.

25. Southwell MT, Wistow G. Sleep in hospitals at night: are patients needs being met? J Adv Nurs 1995;21:1101-9.

26. Şahin Altun Ö, Karaman Özlü Z, Olçun Z, Bağdigen M. Does the fear of surgery prevent patıents from sleepıng? Journal of Anadolu Nursing and Health Sciences 2017;20:259-65.

27. Özdel O, Toker Ugurlu T. Genetics of sleep disorders. Turkiye Klinikleri Journal of Psychiatry -Special Topics 2016;9:88-91. 